\title{
The Use of Scoring Method for Prioritizing
}

\section{the Project Portfolio}

\author{
Liane Mahlmann Kipper \\ Department of Industrial Systems and Processes, University of Santa Cruz do Sul
}

Avenue. Independência, 2293 Santa Cruz do Sul - RS Zip code: 96815-900

E-mail: liane@unisc.br

Elpídio Oscar Benitez Nara (Corresponding author)

Department of Industrial Systems and Processes, University of Santa Cruz do Sul

Avenue. Independência, 2293 Santa Cruz do Sul - RS Zip code: 96815-900

E-mail: elpidio@unisc.br

Julio Cezar Mairesse Siluk

Departament of Production Engineering, Federal University of Santa Maria

Avenue: Roraima, 1000, Santa Maria, RS Zip code: 97105-900

E-mail: jsiluk@ufsm.br

Fabrício Mendes

Department of Engeneering, University of Santa Cruz do Sul

Avenue. Independência, 2293 Santa Cruz do Sul - RS Zip code: 96815-900

E-mail: fabricio.mendes@ibest.com.br

Received: Nov. 28, 2013 Accepted: December 15, 2013 Published: January 1, 2014

doi:10.5296/jmr.v6i1.4636 URL: http://dx.doi.org/10.5296/jmr.v6i1.4636

\begin{abstract}
Focusing in answering to the demand the organizations have for a project portfolio which is able to provide support to its development, the research was guided based on the current concepts and techniques for project managing. For this end, concepts and techniques from PMBOK were studied and applied, besides the Scoring method to prioritize and give support to the management of project portfolios. As a result, it is possible to highlight the application
\end{abstract}




\section{Macrothink}

Journal of Management Research ISSN 1941-899X 2014, Vol. 6, No. 1

of a practical method which uses a technique to measure the benefits to give the projects punctuation properly aligned to the organizational strategic planning. The proposition developed delivered to the surveyed organization a process aligned to good practices in project management, besides contributing to the academic and scientific community showing practical and updated solutions from these methodologies.

Keywords: Project managing, Management of Project Portfolios, Project Prioritization, Strategic Planning 


\section{Introduction}

During the last decades of the $20^{\text {th }}$ Century, only the work carried directly in the manufacturing areas seemed to bring positive results for the companies. Although lately this true has not being absolutely right and more and more the business processes appear to be important allies when searching for new ways to improve the development of organizations in the new millennium. The companies are leaving aside what they think to be important and they are starting to look for this answer with those who are really important: their clients. For Donald (2008), the clients are more conscious about the role they play in the society and prefer products and services from green companies, which do not affect neither safety nor health of the ones related internal and externally with the project, and also have the quality they required. Facing this competitive scenario, the organizations are always looking for operational excellence and quality for their businesses, but without neglecting environmental, health and job safety matters. It is in this bias that the Integrated Management Systems - IMS go in with the certifications of Quality Management with ISO 9001:2008, Environmental Management with ISO 14001:2004 (International Organization for Standardization) and the Safety and Occupational Health Management with OHSAS 18001:2007 (Occupational Health and Safety Assessment Services). The author Gasnier (2000a) consider that the answers to corporative strategies could be obtained through projects, if those are aligned to them. Yet, according to Basgal et al. (2009a), the companies usually their implement their strategies through a project portfolio properly aligned to the Strategic Planning. Because of this finding, this essay had as its goal to identify opportunities to improve project management processes in order to promote support to the strategic alignment and prioritization of projects.

\section{Theorical Embasement}

In Campos (2004) conception, the organizations exist to satisfy the necessities of the clients, and these prefer to use products or services with characteristics they appreciate. To Songsom, (2013) winning customer loyalty is very important because in its concept the loyalty of old customers is cheaper than gain new ones. Stauss et al (2005) also emphasize the importance of customer satisfaction claiming they help spread the fame of the company. According Bhutto et al (2012) satisfaction and customer loyalty has a high relationship with the quality of product and service. This way, the organizations wishing to thrive in this scenario should look forward to improve their processes in a way they can eliminate what "does not add value" to the service or good that matter. Especially in sectors where the level of incertaza is quite high, requiring the deployment of a good strategic vision (Fitsilis et al, 2011). In this context, it was studied the main conceptual foundations used to manage projects, as well as in the application of some of these methodologies building, this way, the base for the knowledge used for the development of this essay.

\subsection{Project management}

An essential step for the systematization in performing a task is the use of a method. In case of projects, it could not be different, mainly because it deals with resources administration, deadlines, besides technical requirements. Silva (2012) reports that there is a strong tendency 
of companies opt for management process to better forecast targets, cost and performance. It is in this context that the PMI - Project Management Institute was created in order to identify the best project managing practices through the publication of the document named "A guide to the Project Management Body of Knowledge - PMBOK”.

According to Sampaio (2008a), the PMBOK guidebook identifies and name processes, knowledge areas, techniques, rules and methods. Yet according to the author, it is not a fixed methodology because it does not distinguish projects, but can be used as reference manual since it organizes the good practices adopted in the area. Nowadays, it is in its $4^{\text {th }}$ edition and it was published for the first time in 1987 (Beware Business Consultancy, 2010). Sampaio (2008b) also highlights that the guidebook is divided in accordance with the nine areas of knowledge, which are: Integration Management, Scope Management, Time Management, Cost Management, Quality Management, Human Resources Management, Communication Management, Risk Management and Supply and Contract Management. The PMBOK guidebook (2004, p. 8) highlights that "the management of projects is the application of knowledge, skills, tools and techniques to the project activities with the purpose of attending its requirements". This task is done through processes which receive inputs and generate outputs. From the production point of view, a project has as goal to provide products, services and processes to satisfy the necessities of the clients, whether internal (another process) or external (consumers). The development of the operation as for its quality, fastness, reliability, flexibility and cost depends directly from these projects (Slack, Chambers and Johnston, (2002). The authors Moroni and Hansen (2006), describe, in a very synthetic way, the five steps of a project:

- Initiation: It's the phase where there are made the presentations of the project, scope definitions, authorizations, etc.

- Planning: That is the phase where the project is refined with the definition of the activities, resources allocation, cost and time estimation, besides the determination of the alternatives to answer the objectives of the project.

- Performance and Control: this is the phase where the project is put into practice and also when the principles for controlling and tracking resources and time are established.

- Closure: this is the phase where all the documents and closure reports are done. It is also the moment to evaluate the positive and negative points as a way of helping the company learning process.

According to what Basgal et al. (2009b) highlights, the companies usually implement their strategies through projects and, in this context, the portfolio alignment or yet portfolios from these projects outlined in the Strategic Planning are critical factors to ensure success and the generation of results. The project management has as goal to bear the fulfillment of the quality, cost and time requirements, but it should also take into consideration the assurance of physical integrity of the workers, the continuity of the processes and the commitment with the environment. 


\subsection{Management of Project Portfolio}

The management of project portfolios consists in a process to control and plan a set of ongoing proposals or projects in order to search the best use for the resources available in the organization aiming to ensure alignment with the strategies of the company (Gasnier, 2000b). It allows organizations to align their projects with strategy, ensuring appropriate resources for projects (KILLEN and HUNT, 2013). “The key decisions in technology strategy are thus choosing the individual 'attractive' projects, but also determining the shape of the portfolio of projects that will support the organization's strategy.” (Kavadias and Loch, 2008a). The author Levine (2005) emphasizes that the PPM - Project Portfolio Management process is the responsible for aligning the projects with the operation of a company. The operation side is represented by PPM - Governance Council, and the projects side is represented by PMO Project Management Office. The same author highlights that the PMO has as its responsibility to supervise the projects. Its task goes from tracking the realizations, reporting to the Governance Council, the status or possible diversions which can compromise the planning activity. This happens mainly because the projects, which constitute the portfolio, are based in a set of expectations about value, potential contribution to the prosperity of the company and the impact in the use of resources. Jerbrant and Gustavsson (2013) emphasize that the challenges found in these environments oganizacionais require a great ability to improvise because of the constant changes in customer needs. Gray and Larson (2009) complement the definition about portfolio management highlighting that besides the projects being aligned to the strategic goals, it is also necessary to establish a prioritization between them. The authors agree with Gasnier (2000c) in relation to the necessity of setting up a logical process for this prioritization, considering that the proposals must necessarily be classified and scored according to financial and non-financial criteria so it is possible to find the best project portfolio for the organization. It is possible to indicate that:

- Financial criteria are the ROI (Return on Investment) and the NPV (Net Present Value) evaluations.

- ROI (Return on Investment: it is the relation between the amount invested and its return (Hirschfeld, 2000a).

- NPV - Net Present Value: it indicates about future payments added to the initial investment and to the actual interest, in other words, it sets an amount in an initial moment, from a cash flow. (Hirschfeld, 2000b).

- Non-financial criteria is the growth in market participation, reduction of the dependence on non-reliable suppliers, protection against government regulations, social responsibility, visibility of a brand, etc. All these criteria are less tangible and aim the strategically alignment.

In research, the authors Killen, Hunt and Kleinschmidt (2008) identified that there are several tools to support the strategically decisions taken, risk evaluations and the allocation of resources for projects. They found the financial criteria would be the most used for portfolio 
management, but the research indicated that the hybrid models as the most suitable ones, once they also contemplate the strategic criteria in searching for a balanced portfolio aligned to the future plans of the organizations. For example, Kavadias and Loch (2008b) observe that whatever the organization, the focus of a technology strategy remains on the definition and the development of the portfolio of projects. Heising (2012a) calls attention, in his article, to the importance of the stage for capturing ideas, once they are going to integrate the project portfolio. He suggests the evaluation of these ideas to happen in three different steps: (1) generation of ideas or opportunities, (2) evaluation and selection of ideas and (3) condensation and clustering of these ideas in proposals for new projects or even their bundling in other existing projects.

For the authors Cooper, Edgett and Kleinschmidt (2002) the necessity of filtering many requests and/or ideas is usually necessary because there is a great number of projects and a small amount of resources to accomplish them. In the authors idea, the companies still sin because they do not establish clear boundaries to define what should or not be done, what ends up resulting in projects that fail in their quality, cost and time. A successful portfolio, according to Heising (2012b), needs to adopt a holistic view of the organization, trying to ensure its financial success, meeting the strategic plan, keeping the balance of its project portfolio, besides preparing it for future challenges. For Heldman (2006a), the selection of the projects must be done by a committee in a formal process of prioritizing and selection, in a way it is possible to identify the list of projects which will be worked in the following years. This process goes through scheduling meetings where the active projects are also monitored. Yet for Heldman (2006b), it is important for the companies to have a methodology for selecting projects, what is going to be used to evaluate the amount that will be given to the organization as a product or a service of the project. The author says that in the PMBOK there are two categories for selection methods: the methods to measure benefits and the mathematical models.

- Mathematical models: they are also known as constrained optimization methods, they use mathematical formulas and complex algorithms, however they are applied only in very complex projects.

- Methods to measure benefits: they are used by most of the selection projects. They use analysis methods and comparative approach in their decision like: scoring models, cost-benefit analysis, contribution methods, cash flow techniques and economic models.

The methods for selecting projects or even decision models are initiation techniques that, when well applied, will support the strategy of the company through the right indication of projects which are more relevant and are aligned to the organizational concerns.

“Typically, decision makers pick a project portfolio based on their experience and subjective preferences. However, as the number of the available projects increases, decision making without quantitative support can carry significant risks”. (Hu et al., 2008, p. 6611).

\section{Methodology}

It was used a exploratory and descriptive methodology, using a bibliographical research and case study, besides describing the techniques used to obtain the results described in section 3 
of this article. For this end, the work was based in a methodology for project prioritizing presented as the following:

\subsection{Method of prioritization Scoring}

The Scoring method (punctuation) developed by Basgal et al. (2009c) wants to simplify the prioritizing process focusing in aligning the project portfolio to the strategic planning of the organization. It was created with the goal of mainly helping the organizations with a lower matureness level in projects or even those which do not have the project management as an end, but as a mean.

According to the authors, the strategic planning reveals what must be reached so that the vision can be accomplished, whereas in this context it is nothing but the portfolio itself characterized by the transition from a pre-implementation stage to an implementation one. The method uses a qualitative-quantitative model or a semi-quantitative model through the attribution of scoring method, in which are applied different values to the criteria and reflecting about it. The projects are individually evaluated regarding the criteria coming from the strategic planning and the sum of their points gives them their score.

The method is built of four steps, as a methodological procedure used in this study and described below:

1. Identify, define and rank the aspects of the sector which has greater strategic relevance in the organization (responsibility: Executive Board and department analyzed);

2. Translate the generic aspects identified in the previews step, into specific criteria related to the nature of the projects developed in the sector, pondering them, in other words, assigning value from 1 to 3 according to its relevance (responsibility: department and its managers);

3. To turn effective the prioritizing of projects which are answering to the strategic goals pursued by the organization, scoring each criterion of a same project from 0 to 3 according to its relations (responsibility: managers).

4. Prioritize the project, multiplying the score by the respective value of the criterion, whereas all these amounts will build a final sum which will confer the score.

By the analysis of the model it is possible to notice the potentiality of the tool regarding the identification of a great sequence of project execution and, consequently, a resource allocation based on clear criteria and aligned to the interests of the organization.

\section{Results and Discussions}

The results and discussions related to the application of the project portfolio management established in the methodology are presented as the following.

\subsection{Strategic Planning Identification}

During a short analysis of the organization's strategic planning, it is possible to identify the demand for leaner and agile processes, based on overcoming the complexity and in the 
creation of a culture where the improvements must be uninterrupted. Generally, there were used items from the Integrated Policy of Quality, Safety, Health and Environment, which represent the strategies of the organization, that will be presented in the following items.

\subsection{Balance of the components from Strategic Planning}

The items from the policy were evaluated by a multidisciplinary group as for its impact in the project management of the organization, whereas it was given three different values, 1 (low), 2 (medium) and 3 (high) according to what follows in table 1 . In this case, the value was based in the existence of development indicators (KPI - Key Performance Indicator) for monitoring the items in the policy, whereas it was given value 1 when there was not KPI, value 2 when there was at least $1 \mathrm{KPI}$ and values 3 when there were at least $2 \mathrm{KPI}$. The valuation of the strategic components was based on monitoring through indicators; this strategy was adopted because it says that the importance of a particular item is related to the existence of metrics for monitoring it.

Table 1. Value of the items from the Policy in Project Management

\begin{tabular}{|l|c|c|}
\hline \multicolumn{2}{|c|}{ Value of the Items from the Integrated Policy Management } \\
\hline $\begin{array}{l}\text { Item from the Integrated Policy } \\
\text { Strategic Project or Legal } \\
\text { Requirement }\end{array}$ & $\begin{array}{c}\text { Is there } \\
\text { KPI? }\end{array}$ & $\begin{array}{c}\text { Value for } \\
\text { Projects }\end{array}$ \\
\hline 1- Leadership & 0 & 3 \\
\hline $\begin{array}{l}\text { 2- Training and Recognition of their } \\
\text { HR }\end{array}$ & 0 & 1 \\
\hline 3- Focusing on Clients and Consumers & 2 & 1 \\
\hline 4- Reduction in costs & 1 & 3 \\
\hline 5- Health and Safety & 2 & 2 \\
\hline 6- Environment & 1 & 3 \\
\hline 7- Continuous improvement & 1 & 2 \\
\hline
\end{tabular}

\subsection{Project Prioritization Execution}

During the application of the methodology for project prioritization, the identification of the values of the projects facing each one of the criteria's component needs special attention, once the process is meant to be objective. The project classification table, according to its alignment with the strategy represented by the Integrated Policy of Quality, Safety, Health and Environment is presented in frame (table) 1 as it follows. 


\section{MInstitute Macrothink $_{\text {Int }}$}

Frame 1. Classification of the Projects According to the Strategic Alignment

\begin{tabular}{|c|c|c|c|c|}
\hline \multicolumn{2}{|c|}{$\begin{array}{l}\text { Value of the Items in the Integrated Policy } \\
\text { for Project Management }\end{array}$} & \multicolumn{3}{|c|}{ Value of the Projects vs. Policy } \\
\hline Item from the Integrated Policy & $\begin{array}{l}\text { Value for } \\
\text { Projects }\end{array}$ & 0 & 1 & 2 \\
\hline $\begin{array}{l}\text { Strategic Project or Legal } \\
\text { Requirement }\end{array}$ & 3 & $\begin{array}{l}\text { Does not } \\
\text { Apply }\end{array}$ & $\begin{array}{l}\text { Project classified as } \\
\text { Strategical }\end{array}$ & Legal Requirement \\
\hline 1- Leadership & 1 & $\begin{array}{l}\text { Does not } \\
\text { Apply }\end{array}$ & $\begin{array}{l}\text { High Administration } \\
\text { approves the project }\end{array}$ & $\begin{array}{l}\text { High Administration is the } \\
\text { responsible or the petitioner for } \\
\text { the project }\end{array}$ \\
\hline $\begin{array}{l}\text { 2- Training and Recognition of } \\
\text { their HR }\end{array}$ & 1 & $\begin{array}{l}\text { Does not } \\
\text { Apply }\end{array}$ & $\begin{array}{l}\text { Employees Training and } \\
\text { recognition }\end{array}$ & \\
\hline $\begin{array}{l}\text { 3- Focusing in Clients and } \\
\text { Consumers }\end{array}$ & 3 & $\begin{array}{l}\text { Does not } \\
\text { Apply }\end{array}$ & $\begin{array}{l}\text { Improvements in } \\
\text { Indicators }\end{array}$ & $\begin{array}{l}\text { Sensible Improvement for the } \\
\text { consumer }\end{array}$ \\
\hline 4- Reduction in costs & 2 & $\begin{array}{l}\text { Does not } \\
\text { Apply }\end{array}$ & Cost Avoidance & Productivity \\
\hline 5- Health and Safety & 3 & $\begin{array}{l}\text { Does not } \\
\text { Apply }\end{array}$ & Ergonomics & Safety \\
\hline 6- Environment & 2 & $\begin{array}{l}\text { Does not } \\
\text { Apply }\end{array}$ & $\begin{array}{l}\text { Reduction of waste } \\
\text { generation }\end{array}$ & $\begin{array}{l}\text { Prevention of Environmental } \\
\text { Impact }\end{array}$ \\
\hline 7- Continuous Improvement & 2 & $\begin{array}{l}\text { Does not } \\
\text { Apply }\end{array}$ & $\begin{array}{l}\text { Reduction in Natural } \\
\text { Resources Consumption } \\
\text { (without financial impact) }\end{array}$ & $\begin{array}{l}\text { Reduction in Natural Resources } \\
\text { Consumption } \\
\text { (with financial impact) }\end{array}$ \\
\hline
\end{tabular}

The operation of the frame follows the following rule: A score from 0 to 3 is given to the projects according to their relation with each one of the items from the Integrated Policy, here considered as Organizational Strategy, whereas the choice of the value must be done following the orientation of the column 'Project Weight vs. Policy' presented in the frame 1.

\subsection{Definition of the Projects Priority}

After evaluating and scoring each one of the eight items, those are individually multiplied by its respective value in the Project Management Policy presented in the column 'Value of the items in the Integrated Policy / Strategy' also presented in Frame 1. At the end of the project evaluation passing through its eight categories, all results are added, giving the final score of the project. In frame 2, it is possible to see examples of Projects which were properly classified, where their scores are presented in the last column. 
Frame 2. Spreadsheet for Management of Project

\begin{tabular}{|c|c|c|c|c|c|c|c|c|c|c|c|}
\hline & \multicolumn{9}{|c|}{ Project Scoring } & \multirow[t]{2}{*}{$\mathrm{S}$} \\
\hline & & Values & 3 & 1 & 1 & 3 & 2 & 3 & 2 & 2 & \\
\hline \begin{tabular}{|l} 
Project \\
Title
\end{tabular} & Status & \begin{tabular}{|c|} 
Strategic \\
Project/ \\
Legal \\
Requirement
\end{tabular} & $\begin{array}{c}\text { Strategic } \\
\text { Project / } \\
\text { Legal } \\
\text { Requirement }\end{array}$ & $\begin{array}{c}1 . \\
\text { Leadership }\end{array}$ & $\begin{array}{l}\text { 2. Training } \\
\text { and } \\
\text { recognition } \\
\text { of their HR }\end{array}$ & $\begin{array}{l}\text { 3. Focusing } \\
\text { in their } \\
\text { clients and } \\
\text { consumers }\end{array}$ & $\begin{array}{l}\text { 4. Reduction } \\
\text { in Costs }\end{array}$ & $\begin{array}{l}\text { 5. Health } \\
\text { and } \\
\text { Safety }\end{array}$ & 6. Environment & $\begin{array}{l}\text { 7. Continuous } \\
\text { Improvement }\end{array}$ & $\begin{array}{l}0 \\
r \\
e\end{array}$ \\
\hline \begin{tabular}{|c|} 
Project \\
D
\end{tabular} & Running & $\begin{array}{c}\text { Legal } \\
\text { Requirement }\end{array}$ & 2 & 1 & 2 & 2 & 2 & 0 & 0 & 1 & 21 \\
\hline $\begin{array}{c}\text { Project } \\
\text { A }\end{array}$ & Finished & Strategic & 1 & 2 & 1 & 1 & 0 & 1 & 2 & 1 & 18 \\
\hline $\begin{array}{c}\text { Project } \\
\text { F }\end{array}$ & $\begin{array}{c}\text { In } \\
\text { planning }\end{array}$ & Strategic & 1 & 0 & 0 & 0 & 0 & 2 & 2 & 0 & 13 \\
\hline $\begin{array}{c}\text { Project } \\
\text { B }\end{array}$ & $\begin{array}{c}\text { In } \\
\text { planning }\end{array}$ & $\mathrm{N} / \mathrm{A}$ & 0 & 2 & 2 & 0 & 2 & 2 & 0 & 0 & 14 \\
\hline $\begin{array}{c}\text { Project } \\
\text { C }\end{array}$ & $\begin{array}{c}\text { In } \\
\text { planning }\end{array}$ & Strategic & 1 & 2 & 0 & 0 & 0 & 1 & 0 & 0 & 8 \\
\hline Project & $\begin{array}{c}\text { In } \\
\text { planning }\end{array}$ & $\mathrm{N} / \mathrm{A}$ & 0 & 1 & 1 & 0 & 0 & 0 & 0 & 0 & 2 \\
\hline $\begin{array}{c}\text { Project } \\
\text { F }\end{array}$ & Open & & 0 & & & & & & & & 0 \\
\hline
\end{tabular}

The proposal for the implementation sequence of each request became to be established in an objective way, in other words, it follows their score according to the following.

- Clear gray: 15 days to start the Planning step (score $>=20$ )

- Gray: 30 days to start the Planning step (score $>=15$ )

- Medium gray: 45 days to start the Planning step (score $>=10$ )

- Dark gray: 60 days to start the Planning step (score $>=0$ )

It was only given a starting time for the planning step, because of the wide diversity in requests, the time for finishing the project cannot be defined in a standardized way. Besides project prioritization, it is necessary to fit them according to their typology, in other words, their justification for business. The typologies used in the organization are presented in frame 3 as the following.

Frame 3. Typology of the projects regarding their justification for business

\begin{tabular}{|l|l|}
\hline Typology & Description \\
\hline Capacity & Improvement or increasing of the current production capacity \\
\hline Productivity & Reduction in costs with manpower, overtime, disruptions or maintenance \\
\hline Replacement & Replacement of equipments which have exceeded their useful life \\
\hline Quality & Investments to improve the quality of the product \\
\hline Accordance & $\begin{array}{l}\text { Investments to fulfill with legislation changes (environment) or the accomplishment of } \\
\text { requirements from PMI }\end{array}$ \\
\hline Innovation & Investments in machinery to manufacture innovative products \\
\hline Strategic & Set the company in a way it can be benefited with opportunities and/or potential problems \\
\hline Others & Another reason that does not match with the previous ones \\
\hline
\end{tabular}


It is important to mention that nowadays the typology is only used as information submitted to the Financial area of the organization. However, it is defined as potential future developments that its evaluation could be added to the score, enriching, this way, the portfolio management process establishing boundaries for each kind of project.

The new process, although it has advantages over the current one, is still fairly hand-operated because it requires formal meetings, e-mail exchange and storing files in network folders. Because of its importance, it is possible to understand that a computer system would increase even more its efficiency.

\section{Methodology for Project Management}

The management of the project portfolio was part of a complete work to redesign all the project management process, which resulted in significant changes in the flow, responsibilities and associated tasks. The new project managing methodology starts to assign to questions as formal decision filters for the validation of changing requests, as well as for its prioritization. This Gates play a crucial role because they are revising events for the requests and decisions taken by the community and not (Go/Kill) of the project. The new process is presented as a scheme with its main steps in picture 1 as the following.

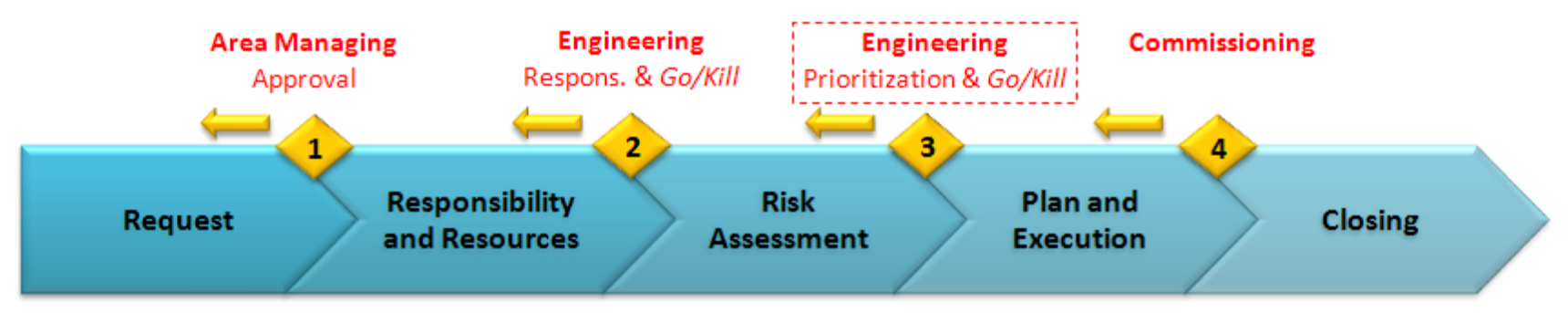

Picture 1. New Project for Project Management Scheme

According to what was showed in Picture 1, the project management process initiates generating request which to go through approval and the definition of the responsibilities. Soon after, the requests are prioritized in a formal meeting through the application of a methodology for Project Scoring. This meeting will initially be performed once a month where it can count with the presence of Managers and Projects Engineers, Occupational Safety and Medicine Department being directed by the Support and Information area of the Engineering Department. The projects will be planned and performed following the prioritization order, and at the end they will be finished and filed. At this moment, it must also be done all the updates in the applicable documentation to match the new context just like the Risk Spreadsheets of the new scenario coming from the development of the project.

\section{Final Considerations}

This world scenario is claiming more and more from the organizations which need to respond to an evolving market with agility and precision. In this regard, this article had as its goal to suggest improvements for the project management process through the inclusion of a prioritization stage to it. The new methodology adds value to the organization when it 
suggests a formal Go/Kill process and the performance of meetings to prioritize projects according to their alignment to the strategic plan of the company. Related to the development and implementation of a methodology which prioritizes projects, it is possible to highlight that this essay presented a solution based on an approach for benefit measurement, where it was used the Scoring method to prioritize the several proposals. It is also important to highlight that a balanced project portfolio is the foundation for the strategic alignment of the organization, once it supports a long-term vision. Because of all the improvements presented during this article, it is possible to conclude that there were delivered fairly relevant results for the company in question, mainly referring to the value given to the client which, from then on, can count on a lean process aligned to the precepts of management by processes and the good practices for project management.

\section{References}

ASSOCIAÇÃO BRASILEIRA DE NORMAS TÉCNICAS (ABNT). (2004). NBR ISO 14001: Sistema de Gestão Ambiental - Requisitos com orientação para uso. $2^{\text {nd }}$ ed. Rio de Janeiro.

Basgal, D. O. et al. (2009). Scoring: Um Método Prático e Simples para Priorização de Projetos. Revista Mundo PM Project Management, 29.

Beware Consultoria Empresarial. (2010). A Metodologia de Gerenciamento de Projetos Methodware. Available from: http://www.beware.com.br/methodware/index.php.

Bhutto, N. A., Azhar, S. M., Sarki, I. H., Khuhro, R. A., \& Arshaad, I. (2012). The Impacto f Customer Satisfaction and Switching Barriers on Customer Loyalty in Pakistani Mobile Telecommunication Services. Journal of Management Research, 4(4). http://dx.doi.org/10.5296/jmr.v4i4.1963.

Campos, V. F. (2004). Gerenciamento da rotina do trabalho do dia-a-dia. (8th ed.) Nova Lima: INDG Tecnologia e Serviços Ltda.

Cooper, R. G.; Edgett, S. J.; Kleinschmidt, E. J. (2002). Optimizing the Stage-Gate Process: What Best Practice Companies Are Doing - Part I. n.14 [online]. Available from: http://www.prod-dev.com/research_articles.php..

. (2002). Optimizing the Stage-Gate Process: What Best Practice Companies Are

Doing - $\quad$ Part II. n.15 [online]. Available from: http://www.prod-dev.com/research_articles.php.

Donald, R. D. M. (2008). Proposição de um Método Integrado de Levantamento de Aspectos/Impactos Ambientais e Riscos à Saúde e Segurança do Trabalho: Um Estudo de Caso do Setor Têxtil. Dissertation (Mestrado em Ciência e Tecnologia Ambiental). University of Vale do Itajaí.

Fitsilis, P., Kirytopoulos, K., \& Leopoulos, V. (2011). Assuring the managerial capability of public organizations implementing projects. International Journal of Managing Projects in Business, 4(2), 329-344. http://dx.doi.org/10.1108/17538371111120270. 
Gasnier, D. G. (2000). Guia Prático para Gerenciamento de Projetos. (1st ed.) São Paulo: Instituto IMAM.

Gray, C. F., \& Larson, E. W. (2009). Gerenciamento de Projetos - O processo gerencial. Tradução de Dulce Cattunda, Frederico Fernandes. (4th ed.) São Paulo: McGraw-Hill.

Heising, W. (2012). The integration of ideation and project portfolio management - A key factor for sustainable success. International Journal of Project Management, 30(5) 582-595. http://dx.doi.org/10.1016/j.ijproman.2012.01.014.

Heldman, K. (2006). Gerência de Projetos: guia para o exame oficial do PMI. Tradução de Luciana do Amaral Teixeira. (3rd ed.) Rio de Janeiro: Elsevier.

Hirschfeld, H. (2000). Engenharia Econômica e Análise de Custos. (7th ed.) São Paulo: Atlas.

Hu et al. (2008). A multi-objective model for project portfolio selection to implement lean and Six Sigma concepts. International Journal of Production Research, 46(23), 6611-6625. http://dx.doi.org/10.1080/00207540802230363.

Jerbrant, A., \& Gustavsson, T. K. (2013). Managing project portfolios: balancing flexibility and structure by improvising. International Journal of Managing Projects in Business, 6(1), 152-172. http://dx.doi.org/10.1108/17538371311291071.

Killen, C. P., \& Hunt, R. A. (2013). Robust project portfolio management: capability evolution and maturity. International Journal of Managing Projects in Business, 6(1), 131-151. Http://dx.doi.org/10.1108/17538371311291062.

Killen, C. P., Hunt, R. A., \& Kleinschmidt, E. J. (2008). Project Portfolio Management for Product Innovation. International Journal of Quality \& Reliability Management, 25 (1), 24-38. http://dx.doi.org/10.1108/02656710810843559.

Levine, H. A. (2005). Project Portfolio Management: A practical guide to selecting projects, managing portfolios and maximizing benefits. (1st ed.) San Francisco: A Wiley Imprint.

Loch, C. H., \& Kavadias, S. (2008). Handbook of New Product Development Management, (5st ed.) Oxford: Elsevier.

Moroni, M. A., \& Hansen, P. B. (2006). Gestão por Processos e a Gestão de Projetos: Um Modelo Gerencial para Alocação de Recursos. Revista Gestão Industrial, 2(1) 47-58. http://dx.doi.org/ 10.3895/S1808-04482006000100005.

OHSAS. (2007). 18001:2007. Sistema de Gestão de Saúde Ocupacional e Segurança. [S.l.].

PMBOK. (2004). Um guia do Conjunto de Conhecimentos em Gerenciamento de Projetos. (3rd ed.) EUA : Newton Square.

Sampaio, M. E. C. (2008). Metodologia de Gerenciamento de Projetos [online]. Available from: http://imasters.com.br/artigo/8392/metodologia_de_gerenciamento_de_projetos. 
Silva, L. A., Damian, I. P. M., \& Pádua, S. I. D. (2012). Process management tasks and barriers: functional to processes approach. Business Process Management Journal, 18(5), 762-776. http://dx.doi.org/10.1108/14637151211270144.

Slack, N., Chambers, S., \& Johnston, R. (2002). Administração da Produção. Tradução de Maria Teresa Corrêa de Oliveira, Fábio Alher. (2nd ed.) São Paulo: Atlas.

Songsom, A., \& Trichun, C. (2013). Structural Equation Model of Customer Loyalty: Case Study of Traditional Retail Shop Customers in Hatyai District, Songkhla Province, Thailand. Journal of Management Research, 5(1). http://dx.doi.org/10.5296/jmr.v5i1.2782.

Stauss, B., Schmidt, M., \& Schoeler, A. (2005). Customer frustration in loyalty programs. International Journal of Service Industry Management, 16(3), 229-252. http://dx.doi.org/10.1108/09564230510601387. 